\title{
Pre-harvest sprouting in cereals
}

\author{
Joseph M. Nyachiro
}

Published online: 24 August 2012

(C) Springer Science+Business Media B.V. 2012

The International Symposium on Pre-Harvest Sprouting (ISPHSC) in Cereals convenes in different locations around the world every 3-4 years. The 1st ISPHSC was in Sweden in August 1975. Subsequent symposia were on a rotating basis in other countries including Detmold, Germany (1998); Kruger National Park, South Africa (2001); Norwich, England (2004) and Mendoza, Argentina (2007). The 12th ISPHSC was in Red Deer, Alberta, Canada from July 24-27, 2011. Around 85 participants from 16 countries attended the 12th ISPHSC. The convening of the 12th ISPHSC was possible through the joint support of Alberta Agriculture and Rural Development, Barley Development Council, Alberta Barley Commission, Perten Instruments, Alberta Innovates Bio Solutions, Alberta Seed Growers' Association, Brewing and Malting Research Institute, Canadian Grain Commission, International Society for Seed Science, Rahr Malting and Unity Scientific. On behalf of the organizing committees, I sincerely extend a big thank you to the

J. M. Nyachiro ( $\square)$

Alberta Agriculture and Rural Development,

Feed Crops Branch, Field Crop Development Centre,

5030-50 Street, Lacombe, AB T4L 1W8, Canada

e-mail: joseph.nyachiro@gov.ab.ca sponsors of the 12th ISPHSC for their generous financial support.

This special issue represents a sample of papers presented at the 12th ISPHSC with the focus on preharvest sprouting and seed dormancy of cereal grains. In total, 62 presentations were made, of which 39 were oral and 23 poster presentations. The international presentations included the latest informative research topics on pre-harvest sprouting and seed science in relation to seed dormancy, plant breeding, molecular genetics and biotechnology, agronomy, seed physiology, seed germination quality and malting, effect on end-use products, baking quality, economic impact, and cereal yield losses due to pre-harvest sprouting.

A rigorous approach was used to develop a wellbalanced program, including reviews and research contributions from acknowledged experts in each area, and submitted research articles. This approach was successful, and I am grateful to the many international scientists and participants who came to Canada for the 12th ISPHSC.

The 12th ISPHSC conference and proceedings will continue to serve as a distinctive meeting and resource that created collaborating opportunity for researchers, industry partners, academia and students in the fields related to cereal crops and seed sciences. The proceedings of previous symposia have been widely cited and they form a solid foundation for current research on pre-harvest sprouting. The proceedings of the past symposia are in: 
1st ISPHSC In: Cereal Res. Commun. Vol 4 (2), 1976.

2nd ISPHSC In: Cereal Res. Commun. Vol. 8 (1), 1980.

3rd ISPHSC In: J.E. Kruger and D.E. LaBerge, eds. Westview Press, Boulder, CO, USA, 1983.

4th ISPHSC In: D.J. Mares, eds. Westview Press, Boulder, CO, USA, 1987.

5th ISPHSC In: K. Ringlund, E. Mosleth and D.J. Mares, eds. Westview Press, Boulder, CO, USA, 1990.

6th ISPHSC In: M.K. Walker-Simmons and J.L. Reid, AACC, MN, USA, 1992.

7th ISPHSC In: Kaz. Noda and D.J. Mares, eds. Osaka, Japan, 1995.

8th ISPHSC In: D. Weipert, ed. Detmold, Germany, 1998.

9th ISPHSC In: Guest Eds. A.Keith Cowan, Euphytica 126: 1-152, 2002.

10th ISPHSC In: CD, Norfolk, England June 7-11, 2004.

$11^{\text {th }}$ ISPHSC In: Guest Eds. R. Benech-Arnold and J. Nyachiro, Euphytica 168: 289-403, 2009.

I am thankful to many people for making the symposium a success. The members of the Local Organizing Committee Jim Helm, Joseph Nyachiro, Jennifer Zantinge, Patricia Juskiw, Lori Oatway, Fran Teitge, Dave Hatcher, Marta Izydorczyk, Pierre Hucl, Robert Hill, and Ron DePauw did a great job of organizing for the 12th ISPHSC. A special recognition goes to Lori Oatway and Frances (Fran) Teitge for their many hours spent on making sure all the logistics (registration, abstracts, communications, transportation, accommodations, website development and sundries) of hosting this conference were in place and not left to chance. Thanks to the members of the International Organizing Committee Joseph Nyachiro (Chair), Amita Mohan, Annelie Barnard, Daryl Mares, John Flintham, Kaz Noda, and Roberto L. BenechArnold for their insightful suggestions that shaped the agenda of the 12th ISPHSC.

The Local Organizing Committee is thankful to the many people that contributed to the success of this symposium. In particular, great appreciation is to the FCDC technical staff for providing support in crucial pre-conference and conference hosting activities.
I wish to thank everybody involved in the organization of the 12th ISPHSC and, in particular, the many people that collaborate in the production of this special issue. Most prominent scientists from around the globe kindly volunteered their time and expertise as reviewers to ensure the scientific quality of the papers comprising this special issue. I would also like to thank my co-editors Dr. Patricia Juskiw, Dr. Camille Steber and Dr. Jennifer Zantinge, who through their knowledge made the demanding job of editing manuscripts much simpler. Last, but not least, I would like to sincerely thank Professor R.G.F Visser, Editor-inChief of Euphytica the International Journal of Plant Breeding, for granting the publication of this special issue. I won't forget to thank Ms. Shobana Ramesh of the Springer Editorial Office who has worked amicably and diligently with the Guest Editors to ensure all manuscripts were in order for publication.

In closing, I would like to thank Dr. Chengdao Li for accepting the lead in organizing the hosting of the 13th ISPHSC to convene in 2015 in Perth, Australia.

\section{About the Guest Editors}

Joseph M. Nyachiro (Guest Editor and Chair of Organizing Committee of 12th ISPHSC 2011), Patricia E. Juskiw, Camille M. Steber and Jennifer L. Zantinge.

Dr. Joseph Nyachiro obtained a B.Sc. (Agric.), from the University of Nairobi, and M.Sc. and Ph.D. (Plant Breeding) from the University of Alberta. He is a Plant Breeder, leading the 6-rowed and hulless barley breeding programs at the Field Crop Development Centre (FCDC) of Alberta Agriculture and Rural Development based at Lacombe since 2001. The FCDC breeding program focuses on developing cultivars with high yielding potential, multiple disease resistance, early maturity, high energy and pre-harvest sprouting resistance, among others. Before coming to FCDC he worked as a Research Scientist of the wheat breeding program at the Federal Research Centre of Agriculture and Agri-Food Canada in Swift Current, SK. Prior to this, Joseph worked at the National Plant Breeding Research Centre in Njoro, Kenya. He has bred and contributed to the development and release of over 25 varieties of wheat, barley and triticale grown in Canada and Kenya; he has also authored and co-authored over 25 scientific papers in refereed scientific journals. Since 
2004, Joseph has been an Associate Editor of Euphytica, the International Journal of Plant Breeding.

Dr. Patricia (Pat) Juskiw obtained a B.Sc. (Plant Science) and M.Sc. (Plant Breeding) from the University of Manitoba, and a Ph.D. (Plant Breeding) from the University of Guelph. Pat has been leading the two-row malt and feed barley breeding programs of the FCDC since 1996. Prior to this, she worked as a Research Agronomist with the FCDC. She has been a leader and collaborator on many scientific projects, including projects on marker-assisted selection for feed quality and disease resistance, nitrogen use efficiency, water use efficiency, malting barley quality, feed efficiency, and multiple disease resistance. Pat has contributed to the development and release of 30 barley and triticale varieties grown in Canada. Pat has published over 50 articles in refereed scientific journals. She served as the Associate Editor of the Canadian Journal of Plant Science from 2001-2006 and is currently an editor for ISRN Agronomy.

Dr. Camille Steber obtained a B.A. (Biology) and a Ph.D in Molecular Genetics and Cell Biology from the University of Chicago, studying the role of the UME6 gene in the control of meiotic divisions. She conducted postdoctoral work under Dr. Peter
McCourt at the University of Toronto, studying the role of gibberellin (GA) signaling in the control of Arabidopsis seed germination before joining the USDA-ARS as a Research Molecular Geneticist in 1998. She holds an adjunct appointment in the Department of Crop and Soil Science at Washington State University in Pullman, WA, USA. Her current projects include research on the role of GA and abscisic acid signaling in the control of seed dormancy, germination, and plant height in wheat and Arabidopsis, and on the mechanisms of drought tolerance in wheat.

Dr. Jennifer Zantinge is the leader of the cereal biotechnology program at the FCDC, Lacombe since 1999. Prior to becoming a Research Scientist at the FCDC, she completed a Ph.D. in molecular biology from the Department of Pathobiology at the University of Guelph. Her research objective at the FCDC is to develop molecular approaches that improve cereal crop protection, yield, and quality. Her current research projects include the development of new molecular markers for economically important traits, the application of marker assisted selection to the breeding program, and the development of molecular tools for disease resistance screening and forecasting. 


\section{Sponsors}

\section{Platinum Level}

Alberta Agriculture \& Rural Development

Barley Development Council

\section{Government of Alberta Agriculture and Rural Development}

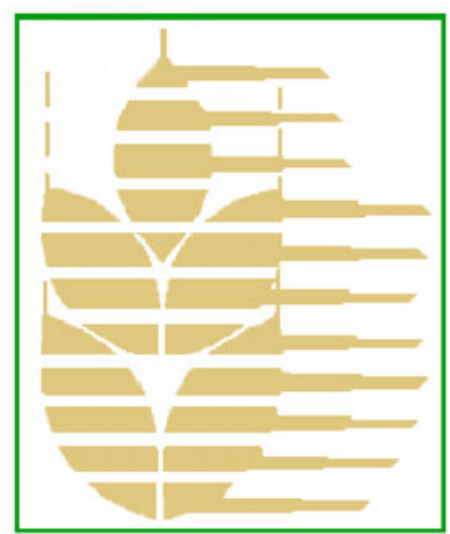

\section{Gold Level}

Alberta Barley Commission

Perten Instruments
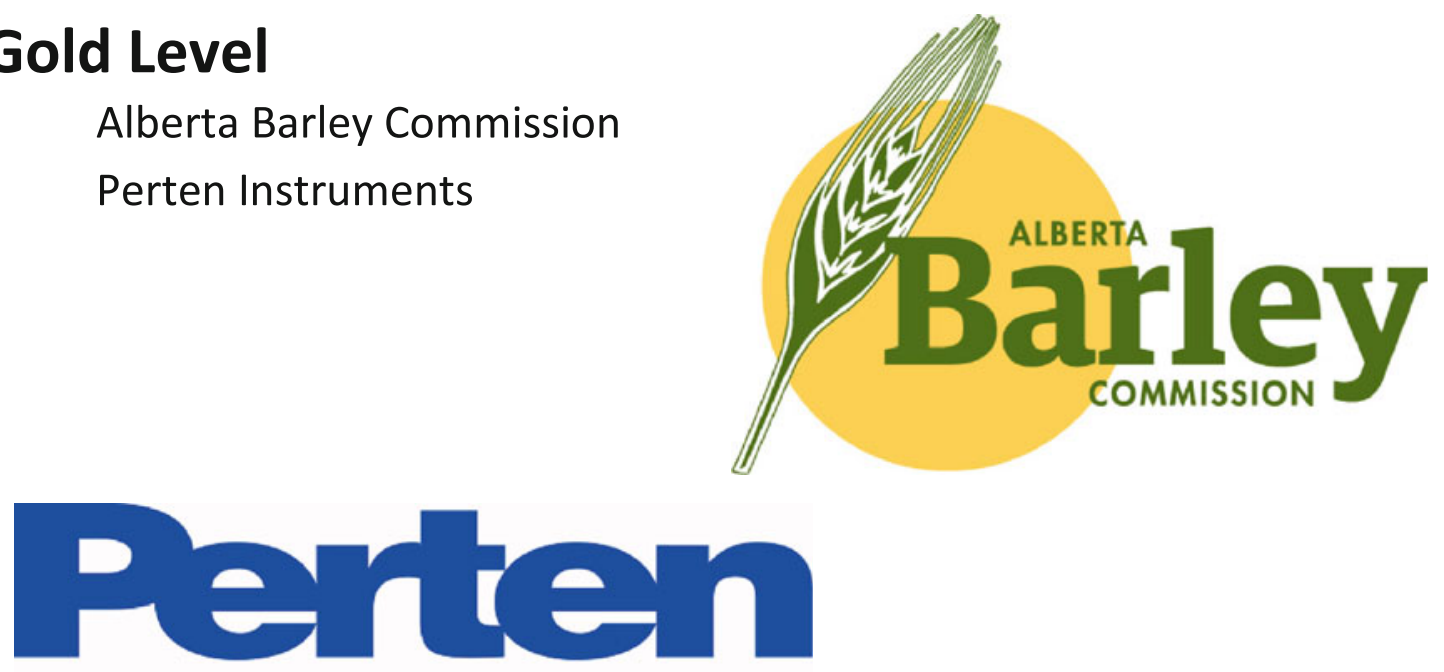


\section{Silver Level}

- Alberta Innovates BioSolutions

- Alberta Seed Growers Association

- Brewing and Malting Barley Research Institute

- Canadian Grain Commission

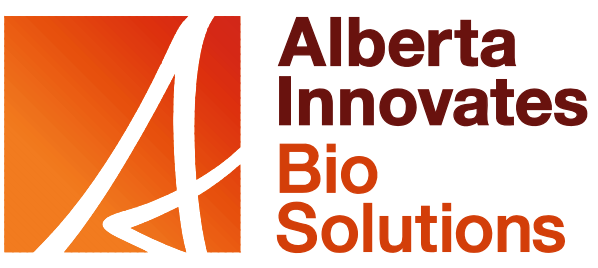

- International Society for Seed Science

- Rahr Malting

- Unity Scientific

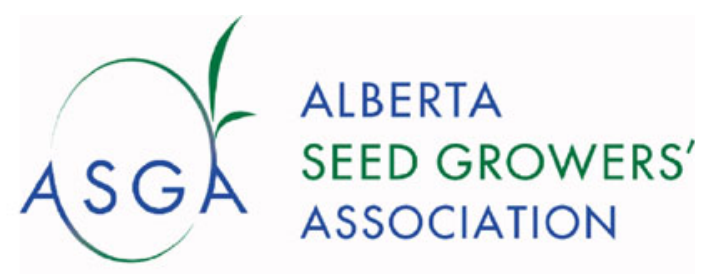

\section{Brewing and Malting Barley Research Institute}

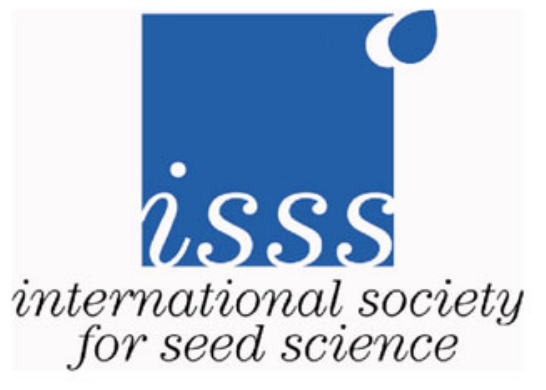

international society for seed science

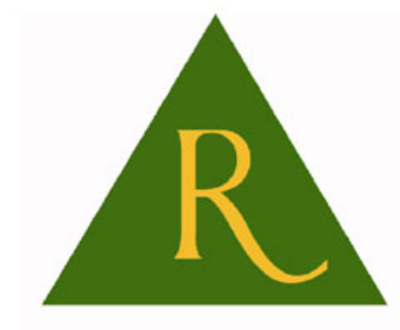

RAHR MALTING 